\title{
God, memory and beauty: A Manichaean analysis of Augustine's Confessions, Book X
}

\begin{abstract}
Author:
Johannes van Oort ${ }^{1,2}$

Affiliations:

${ }^{1}$ Early Christianity and

Patristics, Radboud

University, the Netherlands

${ }^{2}$ Department of Church History and Church Polity, University of Pretoria,

South Africa

\section{Note:}

Contribution to 'Augustine and Manichaean

Christianity', the First South African Symposium on Augustine of Hippo, University of Pretoria, 24-26 April 2012. Prof. Dr Hans van Oort is Professor Extraordinarius in the Department of Church History and Polity of the Faculty of Theology at the University of Pretoria, Pretoria, South Africa.
\end{abstract}

\section{Correspondence to:}

Johannes van Oort

Email:

j.van.oort@planet.nl

Postal address:

Van Renesselaan 24, 3703

AH Zeist, the Netherlands

Dates:

Received: 15 Jan. 2013

Accepted: 21 Feb. 2013

Published: 10 Apr. 2013

How to cite this article: Van Oort, J., 2013, 'God, memory and beauty: A Manichaean analysis of Augustine's Confessions, Book X', HTS Teologiese Studies/Theological Studies 69(1), Art. \#1922, 8 pages. http://dx.doi.org/10.4102/ hts.v69i1.1922

\section{Copyright:}

(C) 2013. The Authors. Licensee: AOSIS OpenJournals. This work is licensed under the Creative Commons Attribution License.

Read online:
The article first sketches some main trends in the recent study of Augustine's Confessions as a work aimed at Manichaean readers. It then detects and analyses the Manichaean-inspired parts in Book X of the Confessions. Augustine's famous theory of memory seems to be directly inspired by Manichaean concepts such as found in the Coptic Manichaean Kephalaia. The article end with a number of conclusions.

\section{The Confessions as a work aimed at Manichaean readers}

The past decades have seen an increasing awareness of the Confessions as a work which at least partly - is aimed at Manichaean readers. One of the pioneers in this field of research was the late Erich Feldmann (1929-1998). In his 1975 Münster dissertation on the influence of Cicero's dialogue Hortensius and Manichaeism upon the young Augustine (Feldmann 1975), he often speaks of Manichaean elements in Augustine's work. This two-volume work was never published. Part of its findings were made available in, for instance, Feldmann's major article 'Confessiones' in the Augustinus-Lexikon (Feldmann 1986-1994:1134-1193). Partly inspired by Feldmann and some other studies (e.g. Courcelle 1968:235-238), I presented my first paper on the question as 'Augustine's Criticism of Manichaeism: The Case of Confessions III, 6, 10 and Its Implications' for a Utrecht colloquium in 1993 (Van Oort 1995:57-68). An expanded version of this paper was presented at a congress in southern Italy and published in 1997 as 'Manichaeism and Anti-Manichaeism in Augustine's Confessiones' (Van Oort 1997:235-248). It was in those years, at the University of Stellenbosch, that I became acquainted with Annemaré Kotzé, who was preparing a dissertation on Augustine's Confessiones. I made some suggestions, provided her with some key articles on Manichaeism, and all this became fruitful in her research. I myself further discussed the subject matter only in my 2000 Nijmegen inaugural lecture on Augustine's Confessions (Van Oort 2002). Annemaré Kotzé, however, took up the research theme in her 2003 dissertation at Stellenbosch University (Kotzé 2004) and, moreover, in a number of articles. Firstly, in her finely tuned 2001 study 'Reading Psalm 4 to the Manichaeans' (with focus on Confessions IX, 4, 8-11) (Kotzé 2001:119-136), after that in 'The Puzzle of the last four Books of Augustine's Confessions: An illegitimate Issue?' (Kotze 2006:65-79), and more recently in research articles such as "The "Anti-Manichaean" Passage in Confessions 3 and its "Manichaean Audience"' (Kotze 2008:187-200) and 'Protreptic, Paraenetic and Augustine's Confessions' (Kotzé 2011:3-23). As may be inferred from these titles, Dr Kotzé approaches the subject from a number of linguistic points of view. Subsequently her research emphasis is on the internal evidence of Augustine's text $^{1}$ - not on the analysis of religio-historical facts, or Manichaean texts proper. Time and again it is highly interesting to see the results of such a linguistic approach finely corroborating the analysis of Augustine's literary corpus with the help of data gleaned from Manichaean texts. I myself still seek to study the subject from a historical and, in particular, religio-historical point of view, ${ }^{2}$ trying to detect where and when Augustine was directly inspired by Manichaean texts and concepts and how (and why) he made use of them either in a positive accepting manner (i.e. consciously or subconsciously integrating Manichaean concepts into his own thinking), or simply in a negative (i.e. anti-Manichaean) fashion.

\section{Main lines of a 'Manichaean' Analysis of Confessions Book X \\ Book $\mathrm{X}$ and its division}

Up to now, the analyses of Manichaean elements in the Confessions mainly focussed on Books III and IX. More or less general remarks have been made on Books XI-XIII as well, and apart from 1.See the explicit remark in Kotze (2001:120-121): : ... can we assume that the Manicheans would read the Confessions? Courcelle (1968:236-237) seems to believe that they did and that Secundinus, a prominent Manichean auditor, alludes to the Confèssions in a letter to Augustine. I argue however, that the strongest evidence for this possibility is internal evidence' (my emphasis).

2.As I did already in my 1986 Utrecht dissertation on Augustine's City of God, the English version of which was published as Van Oort ([1991] 2013). See, for example, page 16. 
some other passages, the same goes for parts of Books I, II, IV and VIII (O’Donnell 1992a: passim, 1992b: passim). Book X of the Confessions, however, being the longest book of the whole work, has been passed over in silence. We will not enter here into the issue of Augustine's composition technique, but only remark that Books I-IX focus on Augustine's past and Books XI-XIII deal with the Creation account of Genesis 1. Between these two distinct parts we find Book $X$, a long discourse on Augustine's present time.

A general division of Book $X$ of the Confessions may be as follows. The first paragraphs provide an extensive introduction (X.1-7), after that Augustine commences his self-analysis (X.8-11), which is followed by his discussion of memory (X.12-28). He subsequently deals with the quest for the happy life and for God (X.29-40), discusses the temptations of human life (X.41-64), and concludes the book by looking back on his inquiry (X.65-66). His very final reflection is on man's reconciliation with God (X.67-70).

\section{Analysis of the opening passage (Confessions X.1)}

As a rule, and in accordance with classical practice, Augustine indicates the theme of a work or book at its beginning. Looking for clues to find the central theme of Book $X$, we read its first paragraph:

Cognoscam te, cognitor meus, cognoscam sicut et cognitus sum. virtus animae meae, intra in eam et coapta tibi, ut habeas et possideas sine macula et ruga. haec est mea spes, ideo loquor et in ea spe gaudeo, quando sanum gaudeo. cetera vero vitae huius tanto minus flenda, quanto magis fletur, et tanto magis flenda, quanto minus fletur in eis. ecce enim veritatem dilexisti, quoniam qui facit eam, venit ad lucem. volo eam facere in corde meo coram te in confessione, in stilo autem meo coram multis testibus. [May I know you, who know me. May I 'know as I also am known' $\{1$ Cor 13:12\}. Power of my soul, enter into it and prepare it for yourself, so that you may have and hold it 'without spot or wrinkle' \{Eph 5:27\}. This is my hope, therefore I speak \{cf. Ps 116:10\}, and in this hope do I rejoice when I rejoice healthfully $\{$ sanum\}. The other things of this life are the less to be wept for, the more they are wept for; and the more to be wept for, the less they are wept for. 'Behold, you have loved the truth' \{Ps 51:8\}, for 'he who does' it 'comes to the light' \{Jn 3:21\}. This I desire to do, in my heart before you in confession, and in my writing 'before many witnesses' \{1 Tm 6:12\}].

At first glance these sentences are quite normal in the context of the work. Augustine confesses that all his hope and joy is in God. Moreover, as is typical for his writing, he intersperses his words with biblical quotes.

A closer look at the opening passage, however, may provide some clues in regard to the specific audience addressed. Previous research has indicated that the intended audience of the Confessions is by no means one-dimensional. Apart from the traditional servi dei (Brown 2000:153), being the spiritually advanced 'servants of God' and the peers of Augustine the bishop and writer, there is a broad spectrum of possible readers, that is, people to be converted to (Catholic) Christianity, recently converted Catholics, Catholic Christians under pressure of Manichaean proselytising, and Manichaeans of diverse rank and conviction. ${ }^{3}$ An important indicator may be the fact that in the immediately preceding Books VIII and IX the Manichaeans and their opinions are addressed directly (e.g. Augustinus, Confessionum libri XIII VIII, 22 \& IX, 9) and that in the Books XI-XIII we find a Genesis exegesis closely connected with Manichaean questions. Thus, something Manichaean might be expected in Book X as well.

A first clue seems to be Augustine's speaking of knowledge in the opening sentence. Manichaeism is a form of Gnosticism and claims to supply saving knowledge. This knowledge ( $\gamma v \tilde{\omega} \sigma 1 \varsigma$, Coptic sayne) is often specified as 'the knowledge of truth' (e.g. Allberry 1938:6, line 23) or 'the knowledge

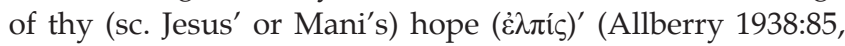
line 25). In a Manichaean text it is stated that 'the youth' (a manifestation of the redeeming Christ figure) reveals itself and that its knowledge and truth and wisdom illuminate the soul. ${ }^{4}$ Augustine's speaking of knowledge, by means of a quote from the well-known Pauline letter 1 Corinthians, ${ }^{5}$ may be considered as indicative. Here we may have a first indication of the subject matter of Book X.

As we have just seen, the Manichaeans claim that Christ's knowledge and truth and wisdom illuminate the soul. Augustine's text continues by saying: 'Power of my soul, enter into it and prepare it for yourself, so that you may have and hold it without spot or wrinkle.' 'Without spot and wrinkle' is reminiscent of Ephesians 5:27 and, moreover, calls to mind the image of a bride. In the Manichaean Psalm-Book

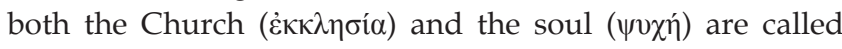
'bride'. ${ }^{6}$ Manichaeism was a form of Christian mysticism, and I still think that the most important impetus of Augustine's own mysticism came from his Manichaean past (cf. Van Oort 1994:126-142, esp. 142). Be that as it may, here we see that his words strongly parallel Manichaean mystical concepts. This observation is all the more valid, because Christ is specified here as virtus, power. ${ }^{7}$ According to Manichaean doctrine, following Paul in 1 Corinthians 1:24, Christ is the wisdom and power of God (see e.g. Faustus, in Contra Faustum Manichaeum XX,2).

The next sentence is remarkable as well: 'This is my hope, therefore I speak (cf. Ps 116:10), and in this hope do I rejoice when I rejoice sanum [healthfully].' In the past the adverb sanum attracted attention. ${ }^{8}$ The uncommon word seems to be used here on purpose. Why? In the Confessions, as in Augustine's other writings, the Manichaeans are the insani, the mad ones (e.g. Augustinus, Confessionum libri XIII IX.8;

3.Kotze (2008:188). Cf. for example, Van Oort ([2001] 2012:163, n. 7) for the Roman Manichaean Secundinus' reading of (parts of) the Confessions. See, moreover Courcelle (1968:236-238).

4.Allberry (1938:105, lines 27-28): 'thy knowledge/and thy truth and thy wisdom illumine the soul.'

5.That is, also well-known to the Manichaeans (see e.g. Böhlig 2013:198-199).

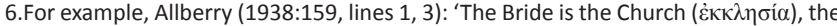
Bridegroom is [...]. /The Bride is the soul ( $\Psi u x n ́)$, the Bridegroom is Jesus.'

7.Cf. for example, Augustinus, Confessionum libri XIII XI.10: 'In hoc principio, Deus, fecisti caelum et terram in verbo tuo, in filio tuo, in virtute tua ...'

8.Cf. Gibb and Montgomery (1927:272): 'The adverb [sc. sanum] is noted as an "addendum lexicis latinis" in Archiv für Lateinische Lexicographie, 1898, p. 52.' 
XIII.45; Contra Faustum Manichaeum XII.6 etc.). Labelling them this way was common practice. Mani, in Greek Móvms, was nicknamed Mavsís, the aorist participle passive of $\mu \alpha i v o \mu \alpha$, to be mad (cf. Van Oort 2000:451-463, esp. 453 ff.). But then it will not be by chance that Augustine stresses his 'sanum gaudium'. Such a joy is not the Manichaeans' joy in madness! Another pointer to a Manichaean context seems to be Augustine's differentiating manner of speaking. 'This is my hope, therefore I speak, and in this hope I rejoice.' Christ who enters his heart is Augustine's real hope, and this reality of faith is called hope in deliberate contrast to the Manichaeans'

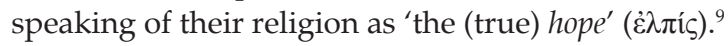

The next sentence is rather obscure. Already its translation causes difficulties, but perhaps we may render it as:

The other things of this life are the less to be wept for, the more they are wept for; and the more to be wept for, the less they are wept for.

Does Augustine refer to his weeping for Monnica in Book IX? But which meaning does he put on this? On the other hand, weeping is an essential element in Mani's religion (see esp. Pedersen 1996:113-115, 200-222). In the Manichaean PsalmBook the name of one of his own (semi)canonical writings is handed down as 'The Weeping' (Psalm-Book 47,1). From other passages in the Psalm-Book we may infer that this writing was often recited ${ }^{10}$ and in one of the Psalms of the Bema it is stated: 'Blessed are thy (i.e. Mani's) loved ones that shed their tears for thee' (Psalm-Book 44,27-28). Is Augustine polemising here against a well-known Manichaean habit and does he assess it as being in inverse proportion to true Christian life style?

The text continues with: "Behold, you have loved the truth" (Ps. 51:8), for "he who does" it "comes to the light" (Jn 3:21).' The word veritas is highly significant, because Mani, in his gospel, already proclaimed himself to be 'I, Mani, apostle of Jesus Christ, through the will of God, the Father of truth $(\dot{\alpha} \lambda \dot{n} \theta \varepsilon 1 \alpha)^{\prime}$ (see Cologne Mani Codex 1985:66) and in his letter to Edessa he stated to speak 'the truth $(\dot{\alpha} \lambda \dot{\eta} \theta \varepsilon 1 \alpha)$ and the secrets' (Cologne Mani Codex 64). From many Manichaean writings and also from Augustine's explicit testimony in Confessions 3.10,11 we know how often the Manichaeans professed to proclaim 'the truth'. Augustine, in all likelihood in opposition to this claim, here confesses his new (Catholic) Christian love for and practice of the truth. In this way, he 'comes to the light'. This turn of phrase seems to be an (antithetical) allusion to the religion preached by Mani, 'the Apostle of Light' (cf. e.g. Psalm-Book 139, 48).

The last sentence of the opening passage restates Augustine's intention to do the truth (1) in confession in his heart coram

9.Such a manner of speaking was already the case with Mani. According to the Cologne Mani Codex, his own gospel is 'the Gospel of his most holy hope ( $\dot{\varepsilon} \lambda \pi \hat{i} c)^{\prime}$

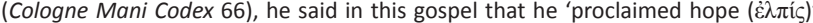
(Cologne Mani Codex 67, 2x), and (in all probability also in this gospel) it was stated that Mani's Syzygos brought to him 'the noblest hope ( $\left.\dot{\varepsilon} \lambda \pi \boldsymbol{i}^{c}\right)$ ' (Cologne Mani Codex 69). In the Coptic Manichaica such as the Psalm-Book and the Kephalaia, passages

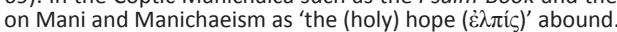

10.Psalm-Book 162, 23-24: 'O Father, o Mind of Light, come and wear me until I have recited the woe [i.e. the weeping] of the Son of Man'. We find the same in PsalmBook 178, 1-2.

11.Augustinus, Confessionum libri XIII 3.10: 'et dicebant: veritas et veritas, et multum eam dicebant mihi ...'; cf. Van Oort (1997:esp. 239ff.).
Deo, and (2) in his writing before many witnesses. Keywords in the passage are truth (veritatem, eam, eam) and knowledge (cognoscam, cognitor, cognoscam, cognitus) and both concepts remind one of the story of Augustine's making acquaintance with Manichaeism in Confessions 3.10. Truth and knowledge are closely related in Manichaeism, for the Manichaean Elect gains knowledge of eternal truth. It seems quite likely that Augustine, who starts here a new section of his writing, ${ }^{12}$ uses these words on purpose. They are pointers to direct the reader's mind towards the writer's intention. Augustine is a converted person, known by God (sicut ego et cognitus sum), and after his conversion comes the transformation of the inner self. ${ }^{13}$ The essence of this transformation is indicated as 'coming to the light' and, in the following chapters of Book $X$, initiated by self-analysis. As seems to be the case in the programmatic introductory paragraph, the terms used in this analysis of the inner self may invoke elements of his Manichaean past.

\section{Beginning the search for God in memory (Confessions X.7ff.)}

Explicit terms that might call up Manichaean matters are sparse in the immediately following paragraphs. Although terms like abyss (abyssus X.2), hidden (occultus X.2) or groaning (gemitus X.2) were well known in Manichaean circles, there seems no reason for ascribing a particular Manichaean meaning to them. The same may go for Christ addressed as 'physician of my most intimate self' (medice meus intime X.3), although it should be noted that such designation is typical of both Augustine (see e.g. Arbesmann 1954a:623-629, 1954b:1-28; Eijkenboom 1960) and the Manichaeans (see e.g. Arnold-Döben 1978:98ff.; Böhlig 1980:247, 249, 255ff.). The immediate context, however, does not provide an indication that the expression should be labelled as 'Manichaean'. ${ }^{14}$ There is a hint at his former co-religionists when Augustine, in his long prayer, says to God that he knows 'that You cannot be in any way subjected to violence' (X.7).${ }^{15}$ We often find this notion in the Confessions, as some standard repertoire of antiManichaean polemic.

The following sections, however, deserve specific attention. After having stated in X.7 that he, being a human person, does not fully know himself, Augustine continues in X.8 by first expounding that the love of God, whose nature is superior to all things, is acquired by the knowledge of the senses. The text of X.8 runs:

Non dubia, sed certa conscientia, domine, amo te. percussisti cor meum verbo tuo, et amavi te. sed et caelum et terra et omnia, quae in eis sunt, ecce undique mihi dicunt, ut te amem, nec cessant dicere omnibus, ut sint inexcusabiles. altius autem tu

12.After he concluded Books I-IX, in which so many sections are specifically aimed at a Manichaean audience. Or even after completing Books I-IX and XI-XIII, in which the second part the Manichaeans and their views seem to be a specific target of polemic.

13.Perhaps one may say, in theological terms, that the iustificatio is followed by the sanctificatio.

14.Cf. Augustinus, Confessionum libri XIII X.39: 'medicus es, aeger sum.' A Manichaean context, however, may be assumed for Confessionum libri XIII II.15 (non me derideat ab eo medico aegrum sanari). See also IV.5 (... sed non ut medicus. nam illius morbi tu sanator, qui resistis superbis, humilibus autem das gratiam). 
misereberis, cui misertus eris, et misericordiam praestabis, cui misericors fueris: alioquin caelum et terra surdis locuntur laudes tuas. quid autem amo, cum te amo? non speciem corporis nec decus temporis, non candorem lucis ecce istum amicum oculis, non dulces melodias cantilenarum omnimodarum, non florum et ungentorum et aromatum suaveolentiam, non manna et mella, non membra acceptabilia carnis amplexibus: non haec amo, cum amo deum meum. et tamen amo quandam lucem et quandam vocem et quendam olorem et quendam cibum et quendam amplexum, cum amo deum meum, lucem, vocem, odorem, cibum, amplexum interioris hominis mei, ubi fulget animae meae, quod non capit locus, et ubi sonat, quod non rapit tempus, et ubi olet, quod non spargit flatus, et ubi sapit, quod non minuit edacitas, et ubi haeret, quod non divellit satietas. hoc est quod amo, cum deum meum amo. [Not with uncertain, but with assured consciousness do I love you, Lord. You pierced my heart with your word, and I loved you. But also the heaven and earth and everything in them, behold, on all sides they tell me to love you. Nor do they cease to speak to all, 'so that they are without excuse' $\{R m$ 1:20\}. But more deeply you will have mercy on whom you will have mercy and will show pity on whom you will have pity $\{R m$ 9:15\}. Otherwise heaven and earth do utter your praises to deaf ears. But what do I love, when I love you? Not corporeal beauty, nor temporal splendour, nor the brightness of the light which, behold, is so pleasant to these \{earthly\} eyes, nor the sweet melodies of all kinds of songs, nor the fragrant smell of flowers, and ointments, and herbs, nor manna and honey, nor limbs acceptable to the embraces of the flesh. It is not these I love when I love my God. And yet I love some sort of light, and sound, and fragrance, and food, and embracement when I love my God - the light, sound, fragrance, food, and embracement of my inner man. It is there that shines unto my soul what space can not contain, it is there that sounds what time snatches not away, it is there that smells what no breeze disperses, it is there that is tasted what no eating diminishes, and it is there that clings what no satiety can part. This is what I love, when I love my God.]

One might say that the famous dictum 'You pierced my heart with your word, and I loved you' is reminiscent of the famous Manichaean concept of 'call and answer'. In Manichaeism the human soul is considered to answer to the call from the heavenly world and, in this way, man becomes a Gnostic. In many Manichaean texts 'call and answer' are even hypostasised as heavenly entities. Moreover, in the Manichaean Psalm-Book it is said that 'Jesus is ... in the heart of his Faithful ( $\pi$ ı兀ós)' (Psalm-Book 161,7-8) and that 'the word of God' [= Christ, Jesus] 'dwells ... in the heart of

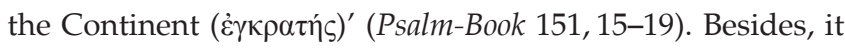
runs in the Psalm-Book: 'since I knew thee, my Spirit, I have loved thee' (Psalm-Book 169,21). All this seems to indicate a Manichaean tradition in the background of Augustine's famous dictum or, at least, some Manichaean flavour. But, on the other hand, perhaps Christ is here 'simply' depicted as some sort of heavenly Cupid, ${ }^{16}$ and so the saying does express the same as Confessions IX.3: 'You pierced my heart with the arrow of your love. ${ }^{\prime 17}$ The last-mentioned dictum became the source of the well-known Augustine emblem of a burning heart pierced with an arrow.

16.See, for example, Chadwick (1991:156, 183). Chadwick (156, n. 2) states: 'The symbol of Christ as heavenly Eros was familiar from the Latin version of Origen's symbol of Christ as heavenly Eros was familiar from the Latin version of Origen's could write of "Christ our Cupid".' As far as I can see, Chadwick is not followed in this opinion.

17.Augustinus, Confessionum libri XIII IX.3: 'Sagittaveras tu corde nostrum caritate tua ...'
The terms used to describe the object of Augustine's love, however, are much more conspicuous in our context:

But what do I love, when I love you? Not corporeal beauty, nor temporal splendour, nor the brightness of the light which, behold, is so pleasant to these (earthly) eyes, nor the sweet melodies of all kinds of songs, nor the fragrant smell of flowers, and ointments, and herbs, nor manna and honey, nor limbs acceptable to the embraces of the flesh. It is not these I love when I love my God.

God is described in terms which unmistakably call to mind Manichaean terms, concepts, and religious practices. It is as if Augustine brings to mind to both himself and his readers the sensory experiences of the Manichaean religious services. According to Manichaean belief, God is Light substance and this Light is dispersed throughout the world, in particular in certain foods. Such foods (fruits like melons, figs, cucumbers and olives) are beautiful and splendid and bright because of their light substance. ${ }^{18}$ During the sacred meals of the Manichaean Elect (which meals are rightly termed 'Eucharist' [see e.g. BeDuhn 2000:14-36]) sweet melodies of all kinds of songs resound (see e.g. the Psalms of the Bema in Allberry 1938:1-47). There is evidence that flowers, ointments, herbs were part of these sacred meals, ${ }^{19}$ and also manna and honey were well known. ${ }^{20}$ Furthermore, it is striking that, in Manichaeism, not only the godly light substance set free through the sacred meal is adored because of its corporeal beauty and so on, but that God and the godly world are being described in the same terms. From the famed Amatorium canticum or 'Song of the Lovers' quoted by Augustine in his Reply to Faustus, ${ }^{21}$ we learn that the Manichaean God was conceived as being crowned with flowers (floreis coronis (inctum ${ }^{22}$ and surrounded by twelve Aeons (duodecim saecula) clothed in flowers (floribus convestita), full of melodious sounds (canoribus plena) and throwing their flowers at the Father's face (in faciem patris flores suos iactantia). Besides, the 'fields' of the godly world are visualised as 'abounding with sweet scent and hills and trees and seas and rivers which flow forever with sweet nectar' (campos ubi scatent aromata, cuius arbores et montes, maria et flumina, dulce nectar fluunt per

18.For example Augustinus, De moribus ecclesiae catholicae et de moribus Manichaeorum 2, 43.

19.See, for example, Gulácsi (2001), in particular the miniatures 36.1, 37.1 and 38.1.

20.See the Hebrew word manna in, for example Psalm-Book 136, 38 and 139, 58. But, curiously, it is also mentioned in Cologne Mani Codex 107 and in Augustinus, Contra Faustum Manichaeum XIX, 22. For honey, see for example, Psalm-Book 158, 27 and $184,13$.

21.Augustinus, Contra Faustum Manichaeum XV, 5-6 (CSEL 25, 425, 4-6): 'annon recordaris amatorium canticum tuum, ubi describis maximum regnantem regem recordaris amatorium canticum tuum, ubi describis maximum regnantem regem, $25,425,16-20)$ : 'sequeris enim cantando et adiungis duodecim saecula floribus $25,425,16-20)$ : 'sequeris enim cantando et adiungis duodecim saecula floribus
conuestita et canoribus plena et in faciem patris flores suos iactantia. ubi et ipsos conuestita et canoribus plena et in faciem patris flores suos iactantia. ubi et ipsos
duodecim magnos quosdam deos profiteris, ternos per quattuor tractus, quibus ille duodecim magnos quosdam deos profiteris, ternos per quattuor tractus, quibus ille
unus circumcingitur.' (CSEL 25, 426, 8-12): 'inuitauit enim te doctrina daemoniorum mendaciloquorum ad fictas domos angelorum, ubi flat aura salubris, et ad campos ubi scatent aromata, cuius arbores et montes, maria et flumina, dulce nectar fluunt per cuncta saecula'; (CSEL 25, 428, 5-16): 'itane tu facie ad faciem vidisti regnantem regem sceptrigerum floreis coronis cinctum et deorum agmina et splenditenentem magnum, sex uultus et ora ferentem micantemque lumine. et alterum regem honoris angelorum exercitibus circumdatum: et alterum adamantem heroam belligerum dextra hastam tenentem et sinistra clipeum: et alterum gloriosum regem tres rotas inpellentem, ignis, aquae et uenti; et maximum Atlantem mundum regem tres rotas inpellentem, ignis, aquae et uent; et maximum Atlantem mundum ferentem humeris, et eum genu flexo brachils utrimque secus fulcientem? haec et alia mille portenta tu facie ad faciem uidisti, an haec tibi doctrina daemoniorum
mendaciloquorum per ora deceptorum cantat et nescis?'

22.Cf. Augustinus, Contra Faustum Manichaeum (CSEL 25, 428, 5ff.): 'the reigning sceptre-bearing monarch bedecked with floral crowns' (regnantem regem sceptrigerum floreis coronis cinctum). 
cuncta saecula). Moreover, in the Manichaean sources the godly Light dispersed throughout the world is identified as 'the members' of God which are enclosed in matter, ${ }^{23}$ which matter is often named 'the flesh' (caro). ${ }^{24}$

\section{God and the five senses}

Augustine's quest for God as the object of his love is described in terms which denote that God is not to be conceived physically, that is not in a physical-material way such as the Manichaeans do. Still in about 400, when Augustine wrote this part of the Confessions, his Gnostic past was at the forefront of his mind.

But the passage in which Augustine commences his selfanalysis deserves more attention. The question is: When I love God, what do I love? His answer runs: it has nothing to do with the five physical senses. Up to now Augustine's speaking of five physical senses has been attributed to his rhetorical training. Is this correct? Five human senses have been distinguished in Greek and Roman philosophy from ancient times onwards and, for Augustine's own time, one may indeed speak of 'a rhetorical device' (O'Donnell 1992b:167). But is, for instance, a classical writer such as Cicero here Augustine's real source? It should be noted that the concept of five senses was well known in Manichaean circles (e.g. Psalm-Book 150,22-26) and, in all likelihood, to Mani himself. ${ }^{25}$ In view of the fact that Manichaean religious practice was so sensory because of its concept of God as physical Light substance, it seems quite likely that in his speaking of God, that is, in his very theo-logy, Augustine is influenced by the Manichaeans' manner of speaking.

Such may already be observed in the next sentences. Although Augustine rejects the idea that direct knowledge of God can be attained via the physical senses, he retains the scheme of the five senses in order to know God. Instead of the physical senses he speaks of their spiritual counterparts. God is a certain light, voice, odour, food and embrace which is sensed by the inner person. The scheme of the five senses (sight, hearing, smell, taste, touch) in order to know God is retained, but clearly in a non-material way: God is sensed by the inner person. Both the material and, as its counterpart, the explicitly non-material manner of speaking seems to be inspired by Manichaean thinking and, moreover, aimed at Manichaean readers in particular.

23.For example, Augustinus, Contra Faustum Manichaeum VI, 4, VI, $8 \cdot$ VIII $2, X I I I$ 6; XIII, 18; XV, 7 et cetera. A fine example as well is Augustinus, Enarrationes in Psalmos 140,12: 'Dei membra uexat, qui terram sulco discindit; Dei membra uexat, qui herbam de terra uellit; Dei membra uexat qui pomum carpit de arbore ... uexat, qui herbam de terra uellit; Dei membra uexat qui pomum carpit de arbore...
Membra iniquiunt, illa Dei quae capta sunt in illo praelio, mixta sunt uniuerso Membra iniquiunt, illa Dei quae capta sunt in illo praelio, mixta sunt uniuerso
mundo et sunt in arboribus, in herbis, in pomis, in fructibus: ... Panem mendicanti mundo et sunt in arboribus, in herbis, in pomis, in fructibus: ... Panem mendicanti
non porrigit; quaeris quare? Ne uitam quae est in pane, quam dicunt membrum Dei, substantiam diuinam, mendicus ille accipiat, et liget eam in carne.' See in the Coptic sources, for example, Psalm-Book 127, 29-31: '... because of the bond which is upon thy (i.e. the Father's) members ( $\left.\mu \dot{\varepsilon} \lambda_{0} \varsigma\right)$ ' and 128, 2: 'thy members ( $\left.\mu \dot{\varepsilon} \hat{\lambda}_{0} \varsigma\right)$ ).

24.For example, Augustinus, Contra Faustum Manichaeum VI, 4: '... ut ipsa dei membra esse credatis, a carnis carcere dimittantur...'; VI, 6: 'Cur autem, si carnibus uesci non uultis, non ipsa animalia deo uestro oblata mactatis, ut ipsa dei membra esse credatis, a carnis carcere dimittantur.' Cf. the quote from Enarrationes in Psalmos 140, 12 above.

25.See the Letter to Menoch which, in all likelihood, is a genuine letter of Mani, quoted in Augustinus Contra secundam Juliani responsionem imperfectum opus III, 175: '. ... sive per visum, sive per tactum, sive per auditum, sive per odoratum, sive per gustum ....'
There is, however, another interesting and even essential aspect. As a rule Manichaeism is considered as representing only a material world view that is only involved with physical substances. Interesting passages in the Kephalaia demonstrate this view to be one-sided. ${ }^{26}$ Firstly, there is a passage in which Mani himself is said to have spoken of the (internal) intellectual qualities of consideration, counsel, insight, thought and mind through which the soul ascends to the Father and the aeons of glory. ${ }^{27}$ Such a passage clearly demonstrates that there is the idea of an internal and mental process of salvation. Besides, many Kephalaia speak of the work of the Light Mind - a Manichaean concept which is close (and probably even identical) to the general Christian concept of the Holy Spirit. ${ }^{28}$ For instance in Kephalaion XXXVIII ${ }^{29}$ it is stated that, according to Mani, this Light Mind or Noũs enters into the Elect and transforms 'the old man' into 'the new $\operatorname{man}^{\prime 30}$ by freeing the five intellectual qualities of mind, thought, insight, counsel and consideration. In this way the Manichaean Elect is transformed into 'a new man', which transformation purifies his spiritual intellect so that he can ascend in his heart ${ }^{31}$ to God the Father. ${ }^{32}$ There even seems to be a text in which God is described as consisting of five great light limbs ( $\mu \dot{\varepsilon} \lambda \eta)$, whilst each of these limbs is connected with an element (light, perfume, voice, etc.) that can be perceived by one of the five senses. ${ }^{33}$

As far as I am aware, therefore, the just analysed passage of Confessions X.8 has an evident Manichaean flavour. In the following paragraphs both Manichaean and anti-Manichaean elements may be detected as well. ${ }^{34}$ Augustine continues his argument by stating that even 'sensing' God with his spiritual faculties does not provide real knowledge of God. One has to delve deeper. Is God the life of the body? This idea is rejected as well: God is not this, but the vitae vita, the life of life (X.10). Neither is He the mind (animus), for also animals have a mind and they also perceive through the body.

\section{God and memory: Confessions X.12-13 and Kephalaion 56 compared}

Augustine continues by asking: Is God then to be found in my memory? We will not follow his full train of thought in this 26.See the Kephalaia, in Polotsky and Böhlig (1940). For my observations I am fully dependent on Gardner (1995).

27.Kephalaia II, in Polotsky and Böhlig (1940:16, 32-23, 12-13). Cf. Gardner (1995:22-26).

28.See, for example, Kephalaia 143, 29.32; 189, 30; 190, 2.3 .6 where the Light Mind is explicitly called 'Holy Spirit'.

29.See the Kephalaia, in Polotsky and Böhlig (1940:89, 18-102, 12); cf. Gardner (1995:93-105).

30.Cf. St Paul and Pauline theology in, for example, Romans 6-7; Ephesians 4:22-23; cf. also 2 Corinthians 4:16; Colossians 3:9.

31.Kephalaia 100, 7-10 in Gardner (1995:103-104): 'He [i.e. the Light Mind] bestows a great spirit upon the elect one. Indeed, now may you find him, as he stands on the earth, rising up in his heart and ascending to the Father, the God of truth.

32.Cf. for this process of transformation and renewing by the Light Nous of the old man into the new man for example, Kephalaia 172, 3-4; 215, 1-5; et cetera.

33.Kephalaia 21, in Polotsky and Böhlig (1940:64, 13-65, 13; Gardner 1995:67-68). Unfortunately the text is rather defective.

34.See, for example, Augustine's speaking of the 'fores carnis meae' in Confessionum libri XIII X.9. The opinion in X.10 that those who are of sound mind (quibus integer sensus est) are those who, like Augustine, hear truth speaking: 'Your God is not earth or heaven or any physical body' (veritas dicit enim mihi: non est deus tuus earth or heaven or any physical body' (veritas dicit enim mihi: non est deus tuus
terra et caelum neque omne corpus) seems to be directed against Manichaean thinking. 
regard, but in particular look at his terminology. Augustine's theory of memory has become world famous and it is not my intention to somehow detract from this fame. But, regarding the sources of his discussions of memory researchers are still rather vague (see e.g. O'Daly 1987; Teske 2006:148-158; O'Donnell 2004-2010:1249-1257). They refer to Platonic and Aristotelian influences in general terms, and also state that Augustine was influenced by eclectic philosophers like Cicero. As regards Platonism, it is of course its doctrine of recollection, still prominent in Middle Platonism and Neoplatonic thinkers like Plotinus, which is indicated as playing an important part in Augustine's considerations. With regard to Aristotelian influences, Aristotle's explanation of the nature of the soul and its relationship to the mind, and how memory proceeds, is deemed to be important. All this does not imply that Augustine himself read works of Aristotle such as De anima (in actual fact we only know of an independent study of Categories (Confessionum libri XIII IV.28), but, like much of the Platonic and, for instance, the Stoic school tradition, the Stagirite's theories seem to have reached him via doxographic works and eclectic thinkers (Stead 1986-1994:445-448). But detecting more precisely philosophical traces of influence on Augustine does not turn out to be simple. I think that one may also (and even explicitly) refer to a certain Manichaean source.

Let us read a part of the curious Manichaean text Kephalaion 56. It runs (in Gardner's [1995:146-148] translation ${ }^{35}$ ) as follows:

138, 20 Once again the enlightener ( $\varphi \omega \sigma \tau \eta \dot{\rho})[=$ Mani] speaks: The moulder $(\pi \lambda \dot{\alpha} \sigma \tau \eta \varsigma)$ placed in the form $(\pi \lambda \dot{\alpha} \sigma \mu \alpha)$ of Adam and Eve limbs $\left(\mu \varepsilon \dot{\lambda} \mathrm{o}_{\mathrm{S}}\right.$ ), outside and within, for perception and activity. He [i.e. Adam, or the human form] was apportioned house by house. ${ }^{36}$ For everything that his perceptions ( $\alpha i \sigma \theta \eta \dot{\tau} \tau \eta \rho \iota)$ and elements ( $\sigma \tau о \chi \varepsilon i \alpha)$ will receive externally there are internal storehouses

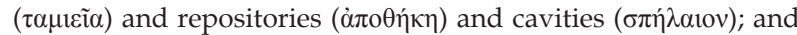
what is received in to them is stored in them. Whenever they will be questioned about what is deposited in their internal storehouses ( $\tau \alpha \mu \varepsilon \approx \alpha \alpha)$, they bring out what they have received within and give it to the questioner ( $\dot{\alpha} \pi \alpha \imath \tau \eta \eta \dot{s}$ ) who requested it of them.

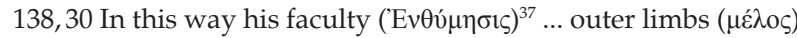
to look at ... every type within ... also the faculty ('Ev0ú $\mu \varepsilon \sigma i \varsigma)$ of the eyes has houses and cavities ( $\sigma \pi \hat{n} \lambda \alpha \iota \mathrm{r})$ and repositories ( $\dot{\alpha} \pi \circ \theta \eta \dot{\kappa} \kappa)$ and stores within, so that every image it might see, whether good or evil, whether loveable or detestable or lustful

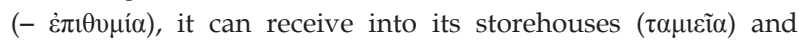

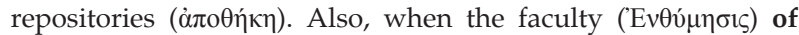
the eyes is pleased to send out the image that it saw and took in, it can go in to its storehouses ( $\tau \alpha \mu 1 \varepsilon i \alpha)$ at the time and think and seek ... and it brings it out and gives it to the questioner

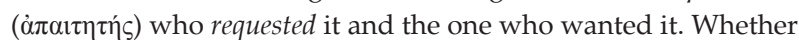
it be something from lust $\left(\dot{\varepsilon} \pi \imath v \mu \mu^{\prime} \alpha\right)$... or an image of love or ...... something hateful. And thus shall that faculty ('Ev $\theta \dot{\mu} \mu \eta \sigma \varsigma \varsigma)$ [of the eyes] produce and do what it does in each category.

35. Italics, bold and the addition of Greek key terms in round brackets and words in square brackets are mine; ... indicate the lacunae in the manuscript. Cf. the original edition in Polotsky and Böhlig (1940:138-140).

36.Gardner (1995:146-148): that is the physical and mental senses are distributed in the appropriate places throughout the body.

37.Gardner (1995:146-148): Lit. 'thought'.
139,15 The faculty ('Ev $\theta v \dot{\mu \eta} \sigma i \varsigma)$ of the ears has its own storehouses $(\tau \alpha \mu 1 \varepsilon i \alpha)$ also. Every sound it might receive, whether good or evil, shall be taken in and placed in its houses and inner repositories

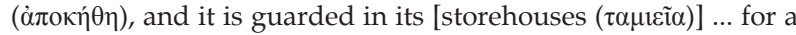
thousand days. After a thousand days, if someone comes and asks that faculty ('Ev $\theta \dot{v} \mu \eta \sigma \varsigma s)$ about the sound that it heard at this time and took into its storehouses ( $\tau \alpha \mu 1 \varepsilon i \alpha)$, immediately it shall go into its repositories ( $\dot{\alpha} \pi \circ \theta \eta \dot{\kappa} \kappa)$ and seek and review and search after this word, and send it out from where it was first put, the place in which it was kept.

$139,25$ In like order, the faculty ('Ev $\theta \dot{\mu} \mu \eta \sigma \varsigma)$ of scent shall function just as that of the eyes and that of the auditory organs. Every odour it shall smell it shall take in to it and deposit in its inner storehouses $(\tau \alpha \mu 1 \varepsilon i \alpha)$. Every time it will be asked by a questioner, it shall go in ... and ... storehouse ( $\tau \alpha \mu \varepsilon \varepsilon \tilde{\varepsilon} \alpha)$ and remember ... only these things.

140, 1 However, even the mouth and the tongue within it, and the taste organ, have a faculty dwelling in them.

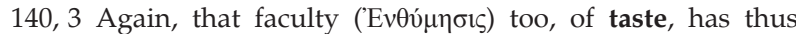

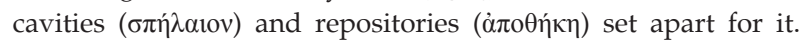
It too receives these tastes and gathers them in. And at any moment when someone will ask of a taste, if ... it shall send it out and remember that taste. It shall snare and give even the mark of that taste; give its memory to the questioner who asks for it.

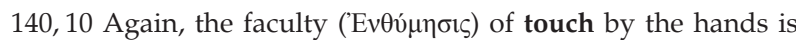
also so: When it might touch, touch shall receive its memory. And it takes it in to its inner repository ( $\dot{\alpha} \pi \circ \theta \eta \dot{\kappa} \kappa)$ until someone will ask this faculty ('Ev $\theta \dot{v} \mu \eta \sigma \varsigma s)$ for the memory. Immediately, it shall go in again and bring out the memory of this touch that it made, and give it to whoever asks for it.

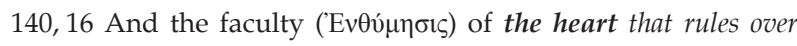
them all is much the most like this. Every thing that these five

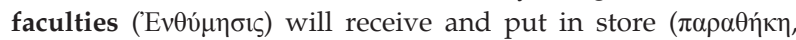

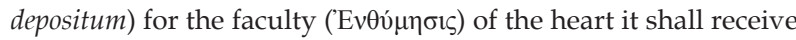
and guard. Any time that they will ask for their deposit it shall send out and give every thing that they gave to it.

It is striking that Augustine, when speaking of memory in Confessions X, 8, 12-13, uses much the same metaphors. He starts speaking of the campi et lata praetoria memoriae [the fields and vast palaces of memory] where are the treasuries of innumerable imagines [images, representations, ideas] of all kinds of objects brought in by sense perception. The same is said by Mani: every image the faculty of the eyes may see is received into its storehouses $(\tau \alpha \mu 1 \varepsilon \tilde{i} \alpha)$ and repositories ( $\dot{\alpha} \pi \mathrm{o} \theta \dot{\eta} \kappa \alpha 1)$. The same goes for the other senses: the faculty of the ears, scent, taste, and touch. One may compare what Augustine says in X.13: it is by the eyes (per oculos), by the ears (per aures), by the nostrils (per aditum narium), by the door of the mouth (per oris aditum) and through the touch (a sensu ... totius corporis quid durum, quid molle etc.) that all sense perceptions enter memory. Also in X.13 it runs: 'Memory's huge cavern (one may compare Mani's cavities, $\sigma \pi \hat{\eta} \lambda \alpha 1 \alpha$ ), with its mysterious, secret and indescribable nooks and crannies (one may compare Mani's storehouses ( $\tau \alpha \mu \imath \varepsilon \tilde{\alpha})$ ) and repositories $(\dot{\alpha} \pi \mathrm{o} \theta \dot{\eta} \kappa \alpha 1)$, receives all these perceptions, to be recalled when needed and reconsidered.' The act of recalling in memory is indicated here by the verb retractare, but earlier, in X.12, Augsutine speaks of posco, I ask/request, and the same is time and again said by Mani (see the first paragraph, 138, 26-29): 'Whenever they will be questioned about what 
is deposited in their internal storehouses ( $\tau \alpha \mu 1 \varepsilon i \alpha)$, they bring out what they have received within and give it to the questioner ( $\left.\dot{\alpha} \pi \alpha \imath \tau \eta \eta^{\prime}\right)$ who requested it of them.' The same 'asking' or better 'requesting' by the questioner ( $\dot{\alpha} \pi \alpha \imath \eta \tau$ ' $\varsigma$ ) is repeated in nearly all next paragraphs. Also, Augustine's next sentence in X.13: 'Each of them enters into memory, each by its own gate, and is put on deposit there' (quae omnia suis quaeque foribus intrant ad eam et reponuntur in ea) has striking parallels in Mani's text: see his speaking of the doors of the senses in Kephalaia 141,14 and later of the 'orifices' or openings of the body such as sight, hearing and smell. These orifices are guarded by guards; we shall return to this shortly.

Of course one might say that all these parallels are coincidental and that, in actual fact, they are due to a common philosophical-rhetorical tradition. There was a strong philosophical and rhetorical tradition indeed, and for Augustine's whole theory of memory and the role of the five senses reference can be made to classical authors like Cicero, (perhaps) Aristotle, and some others. So we might say that also Mani (or his famous disciple Addai/Adimantus, if he is the real author of the Kephalaia) participated in that common tradition as well. And that, via this way, as a Manichaean, Augustine may have been influenced as well.

But apart of all these striking parallels with Augustine's text parallels I could not find in any other classical author - there is more. Augustine's theory of the five senses as the basis of memory is incomplete without his speaking of a certain sixth sense which governs (praesidet) the other senses. This is the sensus interior. Augustine briefly speaks of it in Confessions I.31 and in particular in the second book De libero arbitrio (II, 9-10). In Kephalaia 140, 16 Mani speaks of the faculty

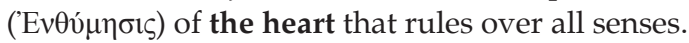

\section{'Great is the faculty of memory' (Confessions X.26), but God transcends it (Confessions X.37)}

In the following sections of Confessions, Book X, Augustine continues his speaking of memory and the senses, the vis or faculty of memory, its storerooms (which are also called cellae in X.16; one may compare Mani's cellarman, $\kappa \varepsilon \lambda \lambda \alpha \rho i ́ \tau \varsigma$, in Kephalaia 140, 27) and so on. He summarises his considerations in X.26: 'Great is the faculty of memory [Magna vis est memoriae], an awe-inspiring mystery. It has its wide fields [campi], its caves and caverns' (cf. Mani's cavities, $\sigma \pi \dot{\eta} \lambda \alpha \iota \alpha)$. Here Augustine is in search of God. He goes on and explicitly states that he does find God in his memory: 'Since the time I learned you, you remain in my memoria [memory, consciousness] and there I find you' (X.37). However, here is a logical problem. 'Since the time I learned you, you remain ...' But, 'where then did I find You?' Of course, so Augustine's reasoning, originally I did not find God in my memory. God far transcends my memory! Originally I did not find God in my memory, since He was far above: 'I found You in Yourself above me': in te supra me.

\section{God and Beauty (Confessions X.38)}

One should note that, until now, Augustine has spoken of finding God in his memory filled (or: nourished, fuelled) by the senses. But, so he says, this does not apply to my first becoming acquainted with God. In his inward search he went the way beyond memory and even beyond his rational mind (animus).

Augustine then arrives at the perhaps most famous passage in the Confessions: he tells of the moment he found God. The passage, in my view, is only fully understandable within a Manichaean context. Not only in Platonic texts (cf. Plotinus, Enneads I.6), but in particular in Manichaean texts God is time and again mentioned as being beautiful, fair, bright. ${ }^{38}$ Once Augustine tried to find God outwardly, 'he plunged into those fair things created by God.' By then he himself was deformis, that is, 'deformed', typically the word he also uses in Confessions IV.31 when he described his Manichaean past. ${ }^{39}$ In X.38 the search for God in memory thus reaches its culmination and end:

Sero te amavi, pulchritudo tam antiqua et tam nova, sero te amavi! et ecce intus eras et ego foris, et ibi te quaerebam, et in ista formosa, quae fecisti, deformis inruebam. mecum eras, et tecum non eram. ea me tenebant longe a te, quae si in te non essent, non essent. vocasti et clamasti et rupisti surditatem meam: coruscasti, splenduisti et fugasti caecitatem meam: fragrasti, et duxi spiritum, et anhelo tibi, gustavi et esurio et sitio, tetigisti me, et exarsi in pacem tuam. [Late have I loved You, o Beauty so ancient and so new. Late have I loved You. And see, You were within and I without, and there did I seek You. I, deformed, I plunged into those fair things which You made. You were with me, but I was not with You! Those things kept me far from You, which unless they had their existence in You, had no existence at all. You called and cried aloud and forced open my deafness. You did gleam and shine, and chase away my blindness. You were fragrant and I drew in my breath, and now pant after You. I have tasted You, and I feel but hunger and thirst for You. You touched me and I'm set on fire for Your peace.]

\section{Conclusions}

Here, at this climactic point, we stop our analysis of the first part of Confessions $\mathrm{X}$, leaving the remaining paragraphs (X.39-70) a subject of future research. Yet, the famous passage Sero te amavi also is the quite natural ending of Augustine's dealing with the theme of God, Memory and Beauty. It is at this juncture that we may wind up with some provisional conclusions.

Firstly, it is crystal clear that Hippo's bishop, when writing Book X some years after 400, still has his former coreligionists at the forefront of his mind. To a certain extent they determined his manner of reasoning and, perhaps even the theme he is dealing with.

Secondly, apart from many small reminiscences, pivotal notions such as Augustine's concepts of God, Memory and Beauty are strongly influenced by Manichaean concepts, mostly in an anti-thetical manner, but in a positive thetical way as well.

38.For example, Psalm-Book 61, 14-15 (for Jesus); 164, 11: .... fair is God ...; 174,11 'Fair ... God ...' Fair here is the refrain et cetera.

39.Augustinus, Confessionum libri XIII IV.31: 'cum deformiter et sacrilega turpitudine in doctrina pietatis errarem. 
Thirdly, Augustine seems to have been acquainted with the contents of the Manichaean Kephalaion 56, either in a direct way (i.e. by hearing or reading a Latin version of this 'Chapter' of Mani's teaching) or indirectly (i.e. by hearing the essentials of this teaching from Manichaean contemporaries or reading them in Manichaean books).

Fourthly, this getting acquainted with Manichaean teaching had a deep effect not only on Augustine, but via his immense influence on our whole intellectual history. Or, stated otherwise, essentials of 'Western' thought on memory in particular, but also on the concept of God as being Beauty, appear to go back to Mani's teaching.

\section{Acknowledgements Competing interests}

The author declares that he has no financial or personal relationship(s) which may have inappropriately influenced him in writing this article.

\section{References}

Allberry, C.R.C. (ed.), 1938, A Manichaean Psalm-Book, Part II, Kohlhammer, Stuttgart. Arbesmann, R., 1954a, 'Christ the medicus humilis in St. Augustine', in Année théologique, Augustinus Magister II, pp. 623-629, Études Augustiniennes, Paris.

Arbesmann, R., 1954b, 'The concept of Christus medicus in St. Augustine', Traditio 10, 1-28.

Arnold-Döben, V., 1978, Die Bildersprache des Manichäismus, in Kommission bei, E.J. Brill, Köln.

Augustinus, 1891, 'Contra Faustum Manichaeum', in J. Zycha (ed.), S. Aurelii Augustin contra Faustum, libri XXXIII, Corpus scriptorum ecclesiasticorum latinorum 25, pp. 249-797, F. Tempsky, Pragae/Vindobonae, Lipsiae.

Augustinus, 1926, 'Confessionum libri XIII', in P. Knöll (ed.), S. Avreli Avgvstini Confessionvm libri tredecim, pp. 1-348, Teubner, Leipzig.

Augustinus, 1992, 'De moribus ecclesiae catholicae et de moribus Manichaeorum', in J.B. Bauer (ed.), S. Aurelii Augustini de moribus ecclesiae catholicae et de moribus Manichaeorum libri duo, pp. 1-224, Hoelder-Pichler-Tempsky, Vindobonae. (Corpus scriptorum ecclesiasticorum latinorum 90).

Augustinus, 2005, 'Contra secundam Juliani responsionem imperfectum opus', in M. Zelzer (ed.), Sancti Augustini Opera, Contra lulianum (Opus imperfectum). M. Zelzer (ed.), Sancti Augustini Opera, Contra lulianum (Opus imperfectum).
Tomus posterior Libri IV-VI, pp. 1-506, Verlag der Österreichischen Akademie der Wissenschaften, Wien. (Corpus scriptorum ecclesiasticorum latinorum 85/2).

Augustinus, 2011, 'Enarrationes in Psalmos', in F. Gori adiuvante I. Spacia (ed.), Sancti Augustini Opera, Enarrationes in Psalmos 101-150, Pars 4: Enarrationes in Psalmos 141-150, pp. 1-304, Verlag der Österreichischen Akademie der Wissenschaften, Wien. (Corpus scriptorum ecclesiasticorum latinorum 95).

BeDuhn, J.D., 2000, 'Eucharist or Yasna? Antecedents of Manichaean food ritual', in R.E. Emmerick, W. Sundermann \& P. Zieme (eds.), Studia Manichaica IV: Internationaler Kongreß zum Manichäismus, Berlin, 14. - 18. Juli 1997, pp. 14-36, Akademie Verlag, Berlin.

Böhlig, A. 1980, Die Gnosis III, Der Manichäismus, Artemis Verlag, Zürich \& München.

Böhlig, A., 2013, Die Bibel bei den Manichäern und verwandte Studien, Brill, Leiden/ Boston.

Brown, P., 2000, Augustine of Hippo: a biography, University of California Press, Berkely/Los Angeles.

Chadwick, H., 1991, Saint Augustine, Confessions: a new translation, Oxford University Press, Oxford.

Cologne Mani Codex, 1985, in L. Koenen \& C. Römer (eds.), Der Kölner Mani-Kodex: Abbildungen und diplomatischer Text, pp. 1-348, Habelt, Bonn.

Courcelle, P., 1968, Recherches sur les Confessions de saint Augustin, De Boccard, Paris.
Eijkenboom, P.C.J., 1960, Het Christus-medicusmotief in de preken van Sint Augustinus, Van Gorcum, Assen.

Feldmann, E., 1975, 'Der Einfluss des Hortensius und des Manichäismus auf das Denken des jungen Augustinus von 373', PhD dissertation, Department of RC Theology, Münster University, vol. I-II.

Feldmann, E., 1986-1994, s.v., 'Confessiones', in C. Mayer (ed.) Augustinus-Lexikon, Schwabe, Basel, vol. 1, pp. 1134-1193.

Gardner, I., 1995, The Kephalaia of the Teacher: The edited Coptic Manichaean texts in translation with commentary (NHMS XXXVII), E.J. Brill, Leiden.

Gibb, J. \& Montgomery, W. (eds.), 1927, The Confessions of Augustine, University Press, Cambridge.

Gulácsi, Z., 2001, Manichaean Art in Berlin Collections, Brepols, Turnhout. PMid:11268775

Kephalaia, 1940, in H.J. Polotsky \& A. Böhlig (eds.), Manichäische Handschriften der Staatlichen Museen Berlin, vol. 1, Kephalaia, 1. Hälfte (Lieferung 1-10), ed. H.J. Polotsky (pp. 3-102) \& A. Böhlig (pp. 103-244), with H. Ibscher, W. Kohlhammer Verlag, Stuttgart.

Kotzé, A., 2001, 'Reading Psalm 4 to the Manichaeans', Vigiliae Christianae 55, 119136. http://dx.doi.org/10.1163/157007201X00124

Kotzé A., 2004, Augustine's Confessions: communicative purpose and audience, Brill, Leiden.

Kotzé, A., 2006, 'The puzzle of the last four books of Augustine's Confessions: An illegitimate issue?', Vigiliae Christianae 60, 65-79. http://dx.doi. org/10.1163/157007206775567933

Kotzé, A., 2008, 'The "Anti-Manichaean" Passage in Confessions 3 and its "Manichaean Audience"', Vigiliae Christianae 62, 187-200. http://dx.doi. org/10.1163/157007208X247665

Kotzé, A., 2011, 'Protreptic, paraenetic and Augustine's Confessions', in J.A. van den Berg, A. Kotzé, T. Nicklas \& M. Scopello (eds.), In search of truth: Augustine, Manichaeism and other Gnosticism: Studies for Johannes van Oort at sixty, pp. Manichaeism and other Gnosticism: Studies for Johannes van Oort at sixt

O'Daly, G.J.P., 1987, Augustine's Philosophy of Mind, University of California Press, Berkeley, CA.

O'Donnell, J.J., 1992a, Confessions, vol. II: Commentary on Books 1-7, Clarendon Press, Oxford.

O'Donnell, J.J., 1992b, Confessions, vol. III, Commentary on Books 8-13; Indexes, Clarendon Press: Oxford.

O'Donnell, J.J., 2004-2010, s.v., 'Memoria', in C. Mayer (ed.), Augustinus-Lexikon, Schwabe, Basel, vol. 3, pp. 1249-1257.

Pedersen, N.A., 1996, Studies in the sermon on the Great War: investigations of a Manichaean-Coptic text from the fourth century, Aarhus University Press, Aarhus.

Polotsky, H.J. \& A. Böhlig (eds.), 1940, Manichäische Handschriften der Staatlichen Museen Berlin, vol. 1, Kephalaia, 1. Hälfte (Lieferung 1-10), edited by H.J. Polotsky (pp. 3-102) \& A. Böhlig (pp. 103-244), with H. Ibscher, W. Kohlhammer Verlag, Stuttgart.

Stead, G.C., 1986-1994, s.v., 'Aristoteles', in C. Mayer (ed.), Augustinus-Lexikon, Schwabe, Basel, vol. 1, pp. 445-448.

Teske, R., 2006, 'Augustine's philosophy of memory', in E. Stump \& N. Kretzmann (eds.), The Cambridge Companion to Augustine, pp. 148-158, Cambridge University Press, Cambridge. PMid:16510886

Van Oort, J., 1994, 'Augustin und der Manichäismus', Zeitschrift für Religions- und Geistesgeschichte 46, 126-142. http://dx.doi.org/10.1163/157007394X00284

Van Oort, J., 1995, 'Augustine's criticism of Manichaeism: the case of Confessions III,6,10 and its implications', in P.W. van der Horst (ed.), Aspects of religious contact and conflict in the ancient world, pp. 57-68, Faculty of Theology, University of Utrecht, Utrecht. (Utrechtse Theologische Reeks).

Van Oort, J., 1997, 'Manichaeism and anti-Manichaeism in Augustine's Confessiones', in L. Cirillo \& A. van Tongerloo (eds.), Atti del Terzo Congresso Internazionale di Studi 'Manicheismo e Oriente Cristiano Antico', Arcavacata di Rende - Amantea, 31 agosto - 5 settembre 1993, pp. 235-248, Brepols Publishers, Turnhout/Leuven.

Van Oort, J., 2000, 'Mani and Manichaeism in Augustine's De haeresibus: an analysis of haer. 46,1', in R.E. Emmerick, W. Sundermann \& P. Zieme (eds.), Studia Manichaica IV: Internationaler Kongreß zum Manichäismus, Berlin, 14. - 18. Juli Manichaica IV: Internationaler Kongreß zum
1997, pp. 451-463, Akademie Verlag, Berlin.

Van Oort, J., 2002, Augustinus' Confessiones: Gnostische en christelijke spiritualiteit in een diepzinnig document, Brepols, Turnhout.

Van Oort, J., [2001] 2012, 'Secundini Manichaei Epistula: Roman Manichaean "Biblical" argument in the age of Augustine', in J. van Oort, O. Wermelinger \& G. Wurst (eds.), Augustine and Manichaeism in the Latin West, Brill, Leiden.

Van Oort, J., [1991] 2013, Jerusalem and Babylon: A Study into Augustine's City of God and the Sources of his Doctrine of the Two Cities, E.J. Brill, Leiden. 